University of Nebraska - Lincoln

DigitalCommons@University of Nebraska - Lincoln

2006

\title{
Microscale controls on the fate of contaminant uranium in the vadose zone, Hanford Site, Washington
}

James Mckinley

Pacific Northwest National Laboratory, james.mckinley@pnl.gov

John M. Zachara

Pacific Northwest National Laboratory, john.zachara@pnl.gov

Chongxuan Liu

Pacific Northwest National Laboratory, chongxuan.liu@pnl.gov

Steven M. Heald

Pacific Northwest National Laboratory, steve.heald@pnl.gov

Brenda Prenitzer

NanoSpective

See next page for additional authors

Follow this and additional works at: https://digitalcommons.unl.edu/usdoepub

Part of the Bioresource and Agricultural Engineering Commons

Mckinley, James; Zachara, John M.; Liu, Chongxuan; Heald, Steven M.; Prenitzer, Brenda; and Kempshall, Brian W., "Microscale controls on the fate of contaminant uranium in the vadose zone, Hanford Site, Washington" (2006). US Department of Energy Publications. 267.

https://digitalcommons.unl.edu/usdoepub/267

This Article is brought to you for free and open access by the U.S. Department of Energy at DigitalCommons@University of Nebraska - Lincoln. It has been accepted for inclusion in US Department of Energy Publications by an authorized administrator of DigitalCommons@University of Nebraska - Lincoln. 


\section{Authors}

James Mckinley, John M. Zachara, Chongxuan Liu, Steven M. Heald, Brenda Prenitzer, and Brian W. Kempshall 


\title{
Microscale controls on the fate of contaminant uranium in the vadose zone, Hanford Site, Washington
}

\author{
James P. McKinley ${ }^{\text {a,* }}$, John M. Zachara ${ }^{\text {a }}$, Chongxuan Liu ${ }^{a}$, Steven C. Heald ${ }^{\text {a }}$, \\ Brenda I. Prenitzer ${ }^{\mathrm{b}}$, Brian W. Kempshall ${ }^{\mathrm{b}}$ \\ ${ }^{a}$ Pacific Northwest National Laboratory, Richland, WA 99352, USA \\ ${ }^{\mathrm{b}}$ NanoSpective, 12565 Research Parkway, Ste 300, Orlando, FL 32826, USA
}

Received 27 October 2004; accepted in revised form 14 October 2005

\begin{abstract}
An alkaline brine containing uranyl $\left(\mathrm{UO}_{2}{ }^{2+}\right)$ leaked to the thick unsaturated zone at the Hanford Site. We examined samples from this zone at microscopic scale to determine the mode of uranium occurrence-microprecipitates of uranyl $\left(\mathrm{UO}_{2}{ }^{2+}\right)$ silicate within lithic-clast microfractures - and constructed a conceptual model for its emplacement, which we tested using a model of reactive diffusion at that scale. The study was driven by the need to understand the heterogeneous distribution of uranium and the chemical processes that controlled it. X-ray and electron microprobe imaging showed that the uranium was associated with a minority of clasts, specifically granitic clasts occupying less than four percent of the sediment volume. XANES analysis at micron resolution showed the uranium to be hexavalent. The uranium was precipitated in microfractures as radiating clusters of uranyl silicates, and sorbed uranium was not observed on other surfaces. Compositional determinations of the 1-3 $\mu \mathrm{m}$ precipitates were difficult, but indicated a uranyl silicate. These observations suggested that uranyl was removed from pore waters by diffusion and precipitation in microfractures, where dissolved silica within the granite-equilibrated solution would cause supersaturation with respect to sodium boltwoodite. This hypothesis was tested using a reactive diffusion model operating at microscale. Conditions favoring precipitation were simulated to be transient, and driven by the compositional contrast between pore and fracture space. Pore-space conditions, including alkaline $\mathrm{pH}$, were eventually imposed on the microfracture environment. However, conditions favoring precipitation were prolonged within the microfracture by reaction at the silicate mineral surface to buffer $\mathrm{pH}$ in a solubility limiting acidic state, and to replenish dissolved silica. During this time, uranyl was additionally removed to the fracture space by diffusion from pore space. Uranyl is effectively immobilized within the microfracture environment within the presently unsaturated Vadose Zone.
\end{abstract}

(c) 2006 Elsevier Inc. All rights reserved.

\section{Introduction}

Uranium is the most abundant radioactive component of the hazardous byproducts of nuclear weapons production at U.S. Department of Energy sites (Riley and Zachara, 1992), and is widespread as an environmental pollutant that originated from mining, milling, and isotopic enrichment activities (Abdelouas et al., 1999). Within the plutonium-production facilities at the U.S. Department

\footnotetext{
* Corresponding author.

E-mail address: james.mckinley@pnl.gov (J.P. McKinley).
}

of Energy's Hanford Site, radioactive liquid byproducts were stored in large buried tanks, constructed in clusters, or 'tank farms.' The BX tank farm, in the central plateau of the site, was constructed from 1946 to 1947, and was used to store and separate solid waste sludges and liquids (Williams, 1999). While 'cascading' sludges tank-to-tank in 1951, an inter-tank pipeline ruptured, and about $350,000 \mathrm{~L}$ of waste were released to ground, including more than $7000 \mathrm{~kg}$ of uranium in an alkaline matrix of sodium carbonate, nitrate, phosphate, and sulfate (Jones et al., 2001). Beneath the tank farm, a groundwater contaminant plume, $250 \mathrm{~m}$ wide and $900 \mathrm{~m}$ long (Dresel et al., 2002), has 
been shown by isotopic uranium analysis to originate from the 1951 leak (Christensen et al., 2004).

The contaminated Vadose Zone has been studied intensively in recent years, particularly with respect to its retention of uranium. Most recently, a representative set of contaminated sediments was collected by drilling and coring (Serne et al., 2002). The work described here was an element of those investigations, although it differed from them with regard to the scale at which the sediments were was examined; the other studies approached the problem through experimentation with bulk core samples to deduce and model processes that affected uranium occurrence or mobility.

Within the other studies of core samples, characterization provided information concerning the vertical distribution of waste components in the sampling transect, and showed that the Vadose Zone retained and was impacted by the waste as it drained to the water table (Serne et al., 2002). Spectroscopic and X-ray diffraction studies of the bulk sediments showed that the uranium was hexavalent, and that the uranyl-bearing mineral was a silicate, likely sodium boltwoodite (Catalano et al., 2004). A study of the sediments to determine the kinetics of uranium removal by dissolution relied in part on the microscale observations of uranium mineralization reported here (Liu et al., 2004). That study used electrolytes of differing composition, and tracked the aqueous uranyl concentration resulting from leaching in suspension. The leach solutions were calculated to reach thermodynamic equilibrium with respect to solid sodium boltwoodite. A dissolution-diffusion model was constructed to describe the evolution of uranyl from its occurrence in microfractures to its mineral-saturation maximum in pore solutions, i.e., the model simulated the removal of uranium from a constrained physical environment. The study described here was complimentary to that work, in that we determined the mode of uranium occurrence, estimated the composition of its solid-phase and aqueous-phase environments, and constructed and tested a reactive diffusion model for its emplacement in microfractures.

The behavior of mobile $\mathrm{UO}_{2}{ }^{2+}$ in contaminated environments is controlled by natural chemical processes. In solution above $\mathrm{pH} 5$, the uranyl ion hydrolyzes, forming aqueous hydroxide complexes and polymers of uranyl hydroxide (Baes and Mesmer, 1976; Grenthe, 1992; Finch and Murakami, 1999). The hydroxy complexes are relatively weak, and in most groundwaters uranyl occurs in stronger complexes with dissolved carbonate (Langmuir, 1978). Uranyl hydroxides may precipitate where the more soluble complexes are absent; otherwise uranyl carbonates (or sulfates) precipitate from the uranyl-complexant solution, or, where dissolved silica or phosphate are available, the relatively insoluble silicate or phosphate minerals precipitate. Mineral precipitation is thus affected strongly by evolving groundwater composition (Garrels and Christ, 1959). In undersaturated solutions, sorption may influence mobility. The uranyl ion has been shown to interact strongly with common and abundant mineral components in natural systems, including metal oxides, aluminosilicates, and carbonates (Maya, 1982; Mikami et al., 1983; Hsi and Langmuir, 1985; Idiz et al., 1986; Lieser et al., 1992; Barnes and Cochran, 1993; Zachara and McKinley, 1993; Morris et al., 1994; McKinley et al., 1995; Prikryl et al., 2001). Generally, uranyl is complexed by negative fixed-charge or amphoteric sites on mineral surfaces. Aqueous complexation reactions, such as those with carbonate or sulfate species, compete with surfaces for dissolved uranyl, and may limit the extent of the sorption reaction.

The retardation and immobilization of uranium in a reactive mobile system is thus a function of the interplay between oxidation-reduction, sorption, and precipitation, affected by reactants and reactions along its flowpath. We expected the advected uranyl in the migrating contaminant plume to interact with solid surfaces either through sorption or precipitation, and specifically looked for uranium in sorbed and precipitated forms. Previous work (Catalano et al., 2004; Liu et al., 2004) suggested that the contaminant uranium was emplaced as uranyl in a process that limited the rate at which it could be extracted by interaction between the bulk sediment and migrating solutions. That process was analogous to reactions occurring along a flowpath, but it apparently operated at microscale; it was investigated, as described here, by the microscale characterization of the solid uranium phase and its location, and by modelling its microscale emplacement processes.

\section{Experimental methods}

\subsection{Sample acquisition}

A borehole was constructed to intersect the contaminant plume beneath the BX tank farm, using a method in which well casing, the "drive barrel," was advanced by driving it from above using a dropped weight. This method had the benefit of not requiring drilling fluids that could potentially alter or contaminate the penetrated sediments. To reach a depth of $80 \mathrm{~m}$ below ground surface (bgs; $2.3 \mathrm{~m}$ below the water table), the borehole was installed in three stages in which the drive barrel diameter was decreased with depth, to form a nested or telescoped sequence of borehole diameters. The drive barrel transition depths were determined by the formation's resistance to penetration. Thirty-five split spoon samples were collected at intervals of approximately $3 \mathrm{~m}$ by driving the split spoon sampler ahead of the casing into undisturbed sediment. (The "split spoon" is a steel cylinder, split into lengthwise halves and fitted with a hardened collar at its leading edge.) Stainless steel split spoon liners were removed from the samplers at the ground surface, sealed in plastic and transported to the laboratory at $4{ }^{\circ} \mathrm{C}$. (The investigated plume originated from a tank within the BX tank farm, which was desig- 
nated 241-BX-102. The borehole was located $21 \mathrm{~m}$ from this tank, and was designated Well 299-E33-45.)

\subsection{Bulk sediment analysis}

Whole sediments removed from split spoon liners were characterized according to their lithologic properties, and were processed to determine selected compositional qualities. Visual estimates of grain-size distributions were tabulated for the construction of a lithologic/stratigraphic column for representational purposes. Moisture contents were determined gravimetrically (ASTM, 1998). A $15-70 \mathrm{~g}$ subsample was placed in a tared container, weighed, and dried at $105^{\circ} \mathrm{C}$ to constant weight. The water content was calculated as the percentage change in weight. For other testing, sediment subsamples were removed in the laboratory and sieved to provide a uniform $<2 \mathrm{~mm}$ size fraction.

Gamma energy analysis (GEA) was used to quantify bulk uranium concentrations. Field-moist samples were counted in $150 \mathrm{~cm}^{3}$ containers on $60 \%$ efficient Ge gamma detectors, efficiency-calibrated using NIST-traceable standards. Spectral analysis was against spectral libraries, and control samples were used for quality control.

The sediments were too dry to effectively extract pore waters, so a 1:1 extraction using deionized water was used to provide analyte for wet-chemical measurements (Rhoades, 1996). Water equivalent in weight to the dry mass of $60-80 \mathrm{~g}$ samples was added to the field-moist samples in screw-top jars, which were sealed and place on an orbital shaker for $1 \mathrm{~h}$. The samples were allowed to settle, decanted, and separated into an unfiltered aliquot for $\mathrm{pH}$, and a filtered $(0.45 \mu \mathrm{m})$ aliquot for cation, anion, and carbon analyses. Analytical results were corrected to the undiluted pore water composition by assuming that only dilution acted during the extraction process. A small subset of duplicate samples were ultracentrifuged at several thousand $g$, for $8 \mathrm{~h}$, to express pore water, which was analyzed for compositional parameters, including $\mathrm{pH}$, inorganic carbon, cations, and anions. Results from the limited number of direct pore water measurements (not shown) were different from the extracted and calculated compositions, due to reaction between the sediment and the deionized water. The influence of cation exchange and carbonate solubility on laboratory leachate compositions has been discussed elsewhere in some detail (McKinley et al., 2005). The extractions provided a good estimate of the relative impact of waste solutions on the Vadose Zone and of the spatial distributions of waste components.

Dissolved cation concentrations were determined using inductively coupled plasma, optical emission or mass spectrometer instruments, with appropriate dilutions (EPA, 2000a,b). Anion concentrations were determined using ion chromatography (not shown). Inorganic carbon was determined using a carbon analyz- er (ASTM, 1988). Acidity was measured on the unfiltered 1:1 aliqout, using a buffer calibrated $\mathrm{pH}$ electrode and meter.

\subsection{X-ray microprobe analysis}

Sediment subsamples were imbedded in epoxy, wafered using a diamond saw, and prepared as $100 \mu \mathrm{m}$ thin sections on fused quartz slides. Measurements were made at the Argonne National Laboratory Advanced Photon Source on the Pacific Northwest Consortium Collaborative Access Team (PNC-CAT) beamline (Heald et al., 1999). The primary X-ray beam was focused using Kirkpatrick-Baez mirrors to a 6-7 $\mu \mathrm{m}$ diameter on the sample surface. The sample was oriented in a precision-translation stage at $45^{\circ}$ to the X-ray beam, and the detectors were oriented normal to the beam. Uranium maps were obtained by monitoring the $\mathrm{U} \mathrm{M}_{\alpha}$ fluorescence line using a wavelength dispersive detector. For use in registration with scanning electron microscope (SEM) images, other elements were monitored also using an energy dispersive detector (not shown). The detection limit was approximately $1 \mu \mathrm{g} \mathrm{g}^{-1}$ for all elements, equivalent to approximately $10^{9}$ atoms within the beam "spot." Fluorescence X-ray intensities were normalized to the ion chamber current generated by the primary X-ray beam at a flux of about $5 \times 10^{11} \mathrm{ph} \mathrm{s}^{-1}$. SEM and X-ray microprobe (XMP) images were superimposed using Adobe PhotoShop.

X-ray absorption spectra were collected using a defocused beam with averaged multiple collections for bulk samples, and, for individual analyses, with a focused beam, from U-containing regions of the thin section after the spatial distribution of $U$ had been mapped; the incident energy was varied while monitoring the X-ray fluorescence. A $\mathrm{Si}(111)$ double crystal monochromator was used with an energy resolution $(\Delta E / E)$ of about $1.4 \times 10^{-4}$. Powdered rutherfordine $\left(\mathrm{UO}_{2} \mathrm{CO}_{3}\right)$ was used to calibrate the beam energy.

\subsection{Electron microscopy}

Thin sections were carbon coated and examined using a JEOL model 6340f SEM, and images were collected using a backscattered electron detector. The surfaces of microfractures were examined also in this manner.

The composition of free-standing uranium mineral grains that were more than $2 \mu \mathrm{m}$ across was determined using energy-dispersive X-ray spectroscopy (EDS). The analysis of small particles was complicated by the unknown geometry of the analyte solid (Goldstein et al., 1992). For thin and irregular bodies, the $\mathrm{X}$-ray generation volume was not defined, inter-element corrections were difficult, and electrons could penetrate the boundary between the target material and its substrate, causing an inaccurate calculation of the characteristic X-ray yield and inter-element X-ray interactions. To aid in evaluating the effects of crystal size and morphology on analytical re- 
sults, the analyte volume for uranium silicate materials in perfect geometry was estimated using an electron flight simulation method (Chernov, 2000). Assuming a hypothetical solid composition of $\mathrm{USiO}_{5}$ and an accelerating potential of $20 \mathrm{keV}$ for the electron beam, the X-ray generating volume was approximately $0.8 \mu \mathrm{m}$ in diameter, projected onto the sample surface, to a depth of approximately $0.6 \mu \mathrm{m}$. The X-ray emission from this volume was a function of depth, with the detectable X-ray intensity dropping from its maximum near the sample surface to approximately $10 \%$ of that maximum at a depth of $0.5 \mu \mathrm{m}$. The calculations indicated that the substrate minerals would contribute significant compositional information during the analysis of uranium particles of imperfect geometry less than $1 \mu \mathrm{m}$ thick.

EDS spectra were collected using a primary beam energy of $20 \mathrm{keV}$ and processed using a ZAF data reduction routine (Oxford Instruments ISIS), which corrected and quantitated characteristic X-ray yields against commercially available mineral standards (CM Taylor standards; compositional details are available at http://2spi.com). The specific standards were, for $\mathrm{U}, \mathrm{UO}_{2} ; \mathrm{C}$, graphite; $\mathrm{Na}, \mathrm{NaCl}$; $\mathrm{Mg}, \mathrm{MgO} ; \mathrm{Al}, \mathrm{Al}_{2} \mathrm{O}_{3} ; \mathrm{Si}, \mathrm{SiO}_{2} ; \mathrm{Ca}$ and $\mathrm{P}, \mathrm{CaPO}_{4} ; \mathrm{Fe}$ and $\mathrm{S}, \mathrm{FeS}_{2} ; \mathrm{K}, \mathrm{KCl} ; \mathrm{Ti}, \mathrm{TiO}_{2} ; \mathrm{Mn}, \mathrm{Mn}$. $\mathrm{C}$ was not found after many analyses, so it was eliminated from the standards table for data reduction purposes. Before compiling results, obviously erroneous analyses were discarded, i.e., analyses for which $U$ was found to be too low to represent a uranium silicate or oxide. Oxygen in the presence of uranium presented analytical problems related to the uncertainty in the absorption of characteristic oxygen X-rays and the differences in effective $\mathrm{X}$-ray generation depth for the two elements (Heinrich, 1981). Oxygen was therefore calculated from cation equivalents.

Compositional analysis of feldspars adjacent to uranium minerals was done using a JEOL 8200 electron microprobe (EMP). The electron beam was set at an accelerating potential of $20 \mathrm{keV}$ and a current of $20 \mathrm{nA}$. Quantitation was against a plagioclase feldspar of composition $\mathrm{An}_{65}$ for $\mathrm{Si}, \mathrm{O}, \mathrm{Al}$, and $\mathrm{Ca}$, and against albite for $\mathrm{Na}$ (again, compositional details are available at http:// 2spi.com).

Fracture areas including uranyl silicates were prepared for transmission electron microscopy (TEM) using an FEI 200TEM focused ion beam system. The fracture surface, exposed on a polished thin section, was stabilized through the FIB deposition of a Pt layer. A ca. $\sim 2 \times 20 \mu \mathrm{m}$ pillar of material was milled free from the bulk using the focused $\mathrm{Ga}$ ion beam. The pillar was lifted and Pt-welded onto a Cu-ring TEM half grid. Once secured to the TEM grid, the Pt-supported fracture face and fracture fill material were milled to a slab of uniform ca. $\sim 200 \mathrm{~nm}$ thickness for subsequent TEM analysis. For imaging, EDS, and selected-area electron diffraction (SAED) analysis, we used an FEI Tecnai F30 TEM, operating at $300 \mathrm{keV}$ and equipped with a Gatan Imaging Filter (GIF). This methodology has been described in more detail elsewhere (Prenitzer et al., 1998; Heaney et al., 2001; Lomness et al., 2001).

\subsection{Diffusive transport modelling}

The diffusive transport model was constructed as described below using FORTRAN77. The diffusion calculations were iterative, and, on each iteration, were coupled to the geochemical modelling code GMIN (Felmy, 1995), which used a constrained minimization of the Gibbs free energy to speciate aqueous components. Although the waste was released at $60-80{ }^{\circ} \mathrm{C}$, the temperature at the reaction depth was unknown. Calculations were performed at $25^{\circ} \mathrm{C}$, a limitation of the speciation code. The effects of temperature on reaction rate and equilibrium were unknown, likely to be significant, and within the range of overall uncertainties of the modelling approach.

\section{Results}

\subsection{Drilling and sampling results}

The subsurface in the vicinity of Tank BX-102 was occupied by the Pleistocene sands and gravels of the Hanford formation, unconsolidated fluvial deposits containing lithic clasts of mafic, granitic, and metamorphic origin (Bjornstad, 1990). The sediment profile (Fig. 1), included intervals of predominantly sand and gravel, interrupted by relatively thin silty zones. Fifty years after the spill, the uranium was concentrated primarily within two zones, centered at about $25 \mathrm{~m}$ and $40 \mathrm{~m}$ bgs, in sandy sediments, at depths intermediate above the water table $(77.7 \mathrm{~m} \mathrm{bgs})$. The sediment column had drained sufficiently to re-establish natural moisture contents of approximately $3 \mathrm{wt} \%$. The sediment $\mathrm{pH}$ was modified within the zone impacted by tank waste, about $23-44 \mathrm{~m}$ bgs, from circumneutral to a relatively alkaline $\mathrm{pH}$ of 9. Major solute cations and anions, represented in Fig. 1 by $\mathrm{Na}^{+}$, were chromatographically separated from uranium in the sediment column, with concentration highs occurring at a depth of approximately $49 \mathrm{~m}$ bgs, but bicarbonate (not shown) was more broadly distributed, and showed a maximum concentration higher in the profile, at $37 \mathrm{~m}$ bgs.

\subsection{X-ray microprobe analysis}

The combined XMP and SEM examination provided sensitive detection for uranium, while maintaining high optical resolution for phase identification. Uranium was within the interiors of sediment clasts (Fig. 2), but was associated with a restricted number of clasts within the sediment as a whole. XANES analysis of bulk sediments and of areas at the scale of the focused X-ray beam (Fig. 3) indicated that only $\mathrm{U}(\mathrm{VI})$ was present. This result complimented the previous study on whole sediments (Catalano et al., 2004), by showing that U(VI) had not been partially reduced at the microscale. 

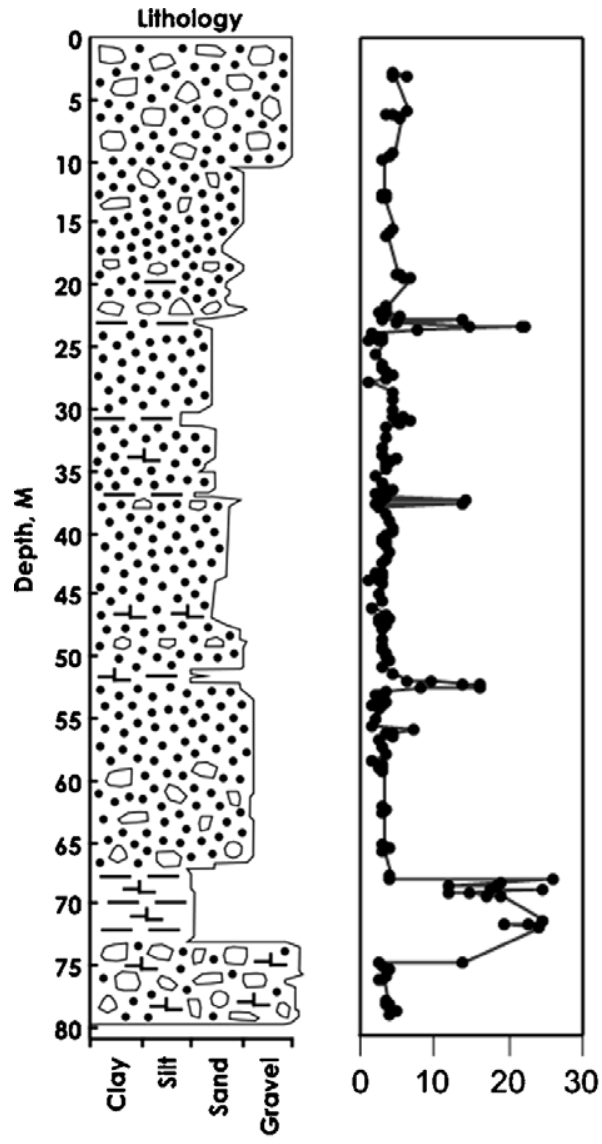

Moisture, \%

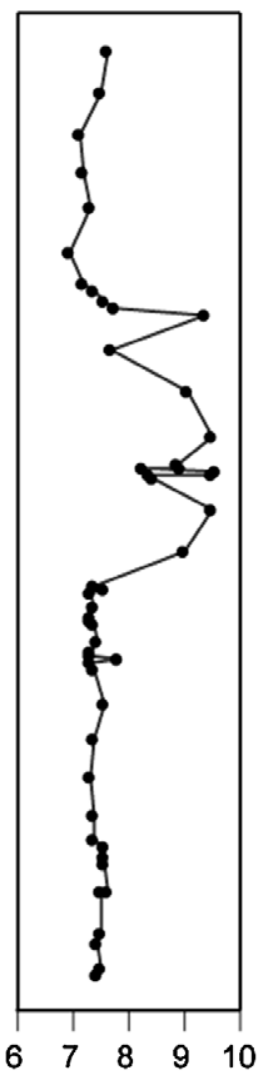

$\mathrm{pH}$

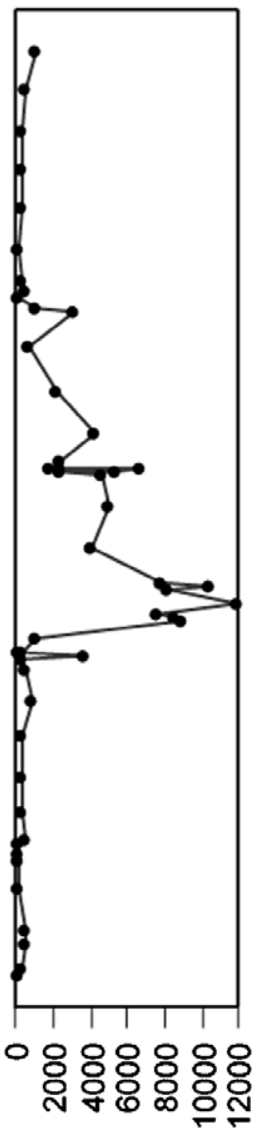

$\mathrm{Na}, \mathrm{mg} / \mathrm{L}$

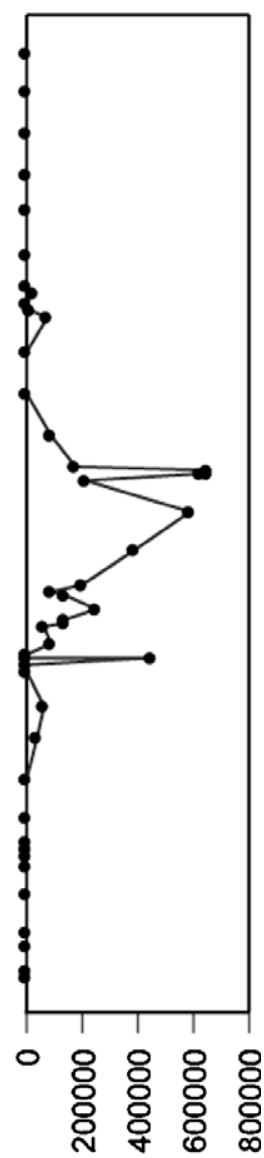

$U, \mu g / L$

Fig. 1. Stratigraphy, moisture, $\mathrm{pH}$, and selected extractable ion concentrations for sediments impacted by a spill of uranium-contaminated waste.
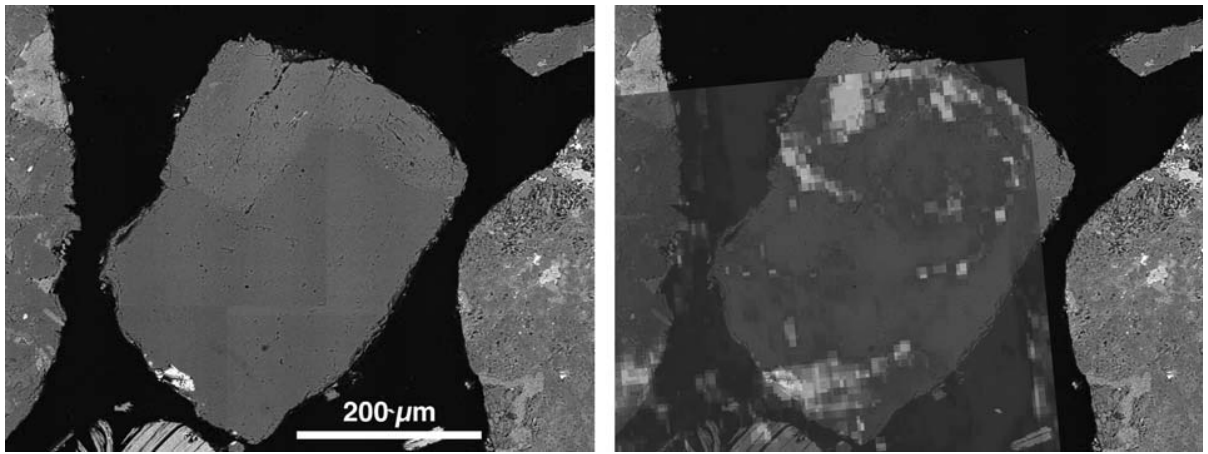

Fig. 2. Granitic sediment clast in SEM backscattered electron image and with partially transparent XMP grayscale overlay. The grayscale spectrum indicated the greatest abundance of uranium in lighter shades. Uranium inclusions were most common in granitic clasts.

\subsection{Electron microscopy}

To determine the distribution and phase(s) of residence for uranium within the contaminant plume, we examined samples from locations with the highest uranium concentration, at depths $35.7,39.5$, and $42.5 \mathrm{~m}$ (Fig. 1). Precipitated uranyl silicates occurred in clast voids and microfractures, predominantly within granitic clasts (which comprised less than $4 \%$ of the total sediment (Bjornstad, 1990)), composed of potassium feldspar, plagioclase, and quartz. In addition, within granitic clasts, it was noted that the uranium was preferentially associated with the plagioclase feldspar mineral component (Fig. 4). The precipitates were minute, generally $1-3 \mu \mathrm{m}$ across, with bladed habit in fractures up to a few micrometers across. Precipitates that appeared to be at the surfaces of silicate clasts in the relatively low-resolution XMP results (Fig. 2; the X-ray beam was focused to a diameter of $7-10 \mu \mathrm{m})$ were, in fact, associated with microfractures near the clast surfaces, and were not observed to be exposed to interclast pore 


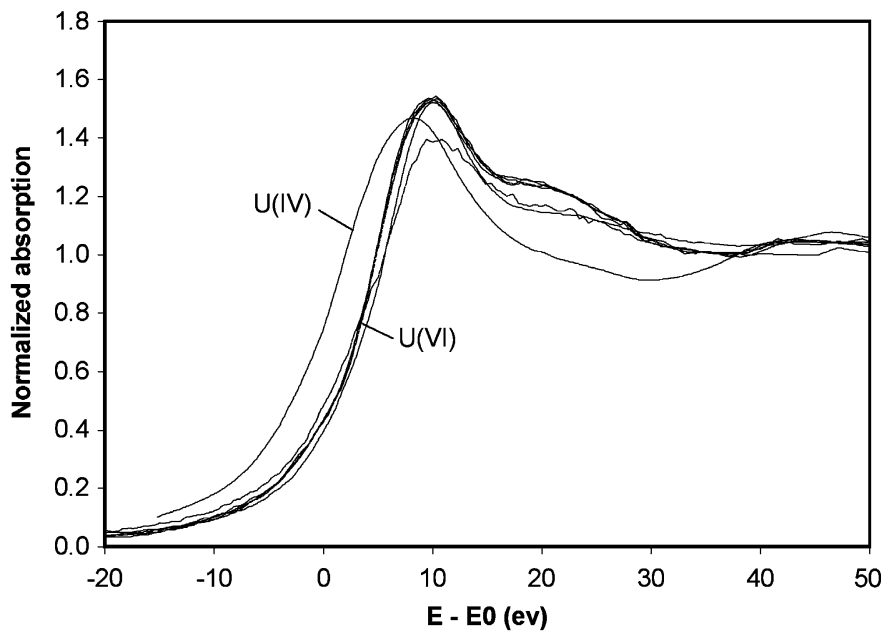

Fig. 3. XANES spectra. All spectra from bulk measurements and from spot measurement for samples collected at 39.5 and $42.5 \mathrm{~m}$ bgs originate from $\mathrm{U}(\mathrm{VI})$. Notations for $\mathrm{U}(\mathrm{VI})$ : rutherfordine, $\mathrm{UO}_{2} \mathrm{CO}_{3} ; \mathrm{U}(\mathrm{IV})$ : $\mathrm{UO}_{2}$, which plots to the left of other spectra.

space. Inspection of XMP and SEM images together produced no evidence of sorbed uranium, i.e., all detected uranium could be ascribed to a solid uranium phase.

To examine the distribution of $U$ within single fractures, granitic clasts were isolated based on surface texture and color, and crushed just until broken. The clasts tended to break along planes of weakness, i.e., along the microfractures, and the surfaces revealed the distribution of precipitates within single fractures (Fig. 5). Uranium silicates were widely disseminated across a given fracture face, occurring as fine acicular crystals, in radiating sprays and often defining mineral florets.

We collected EDS spectra from the thickest uranium mineral clusters. As discussed above, we assumed that the small crystals and crystal clusters we analyzed would allow penetration by the electron beam. The penetrating electrons would necessarily stimulate characteristic X-radiation from surrounding minerals and provide a composite signal to the spectrometer. The set of normalized analyses was screened to eliminate compositions that included too little uranium; many of the uranium-bearing crystals were translucent to the electron beam (note the shading in some florets in Fig. 5), and $\mathrm{UO}_{3}$ concentrations of less than $35 \mathrm{wt} \%$ were considered to include too large an exogenous component. For the remaining analyses, it was difficult to determine the proportions of X-rays from the uranyl analyte and from the substrate. As an ad hoc screen, the mean and standard deviation of compositional results for each measured element were calculated, and elements whose $1 \sigma$ standard deviation was greater than one half the mean were considered to originate predominantly from outside the uranyl analyte. The rationale for this procedure was that the uranyl mineral components would be present at constant ratios (for a single uranyl phase), but the substrate components would likely vary in excited volume, and supply more variable characteristic X-ray fluxes over the set of analytical results. The elements $\mathrm{Mg}, \mathrm{P}, \mathrm{S}, \mathrm{Ca}, \mathrm{Ti}, \mathrm{Mn}$, and $\mathrm{Fe}$ were eliminated by this process. The remaining elemental components ( $\mathrm{Na}, \mathrm{K}, \mathrm{Si}$, and $\mathrm{U}$ ) were considered to comprise the uranyl mineral. The normalized $\mathrm{wt} \%$ composition from this process, and the standard deviations of the set of elemental determinations, are presented in Table 1.

The removal and TEM examination of intact uranyl silicate crystallites within a microfracture from the area shown in Fig. 4C showed the crystallite morphology and crystal habit in more detail (Fig. 6). The uranyl silicate blades occupying the fracture space were of variable electron transparency. At high magnification (Fig. 6, inset), the blades were observed to consist of nanocrystalline material, with crystalline domains of ca. $10 \mathrm{~nm}$ or less, showing a consistent minimum d-spacing of approximately $0.32 \mathrm{~nm}$ in electron lattice images. This spacing was less than the spacing of approximately $0.68 \mathrm{~nm}$ that Catalano used to determine the probable presence of sodium boltwoodite in these sediments (Catalano et al., 2004). Electron diffraction (not shown) produced two broad, indistinct diffraction rings that were not useful in mineral identification. Also, EDS analysis (not shown) indicated that the fracturefill material was of variable composition, including uranium, silicon, oxygen, and the elemental components $\mathrm{K}$, $\mathrm{Ca}$, and $\mathrm{Na}$. The mineralogy of the fracture-filling uranyl silicates apparently varied according to the availability of these elements during precipitation, resulting in nm-scale domains of uranophane-group minerals.

Plagioclase feldspars shown in Fig. 4 had uniform compositions, within EMP counting statistics. Plagioclase feldspars have continuous compositional variations between end-member albite, $\mathrm{NaAlSi}_{3} \mathrm{O}_{8}(\mathrm{Ab})$, and anorthite, $\mathrm{CaAl}_{2-}$ $\mathrm{Si}_{2} \mathrm{O}_{8}(\mathrm{An})$, and compositions may be expressed as subscript percentages of their albite $(\mathrm{Ab})$ component. The series is also arbitrarily divided and named according to its composition within six divisions (Mason and Berry, 1968). The plagioclase shown in Fig. 4 was $A b_{77}$, oligoclase.

\section{Discussion}

The results of chemical extractions from core samples suggested that chemical reactions within the sediment column, between dissolved uranyl and the enclosing sediments, removed uranyl from solution as the waste plume migrated to depth; the uranium was partially separated from solute ions, such as sodium (Fig. 1), that moved with little retardation. Also, bicarbonate concentrations (not shown) were higher than those in uncontaminated sediment, but did not closely parallel changes in uranium concentration over the same depths, suggesting that the removal of uranyl from solution was not accompanied by the removal of carbonate.

The compositional analysis of uranyl minerals (Table 1) was intended to provide a more conclusive identification of the uranyl-bearing phase than was produced by the deductive methods of sediment leaching studies (Liu et al., 2004). 


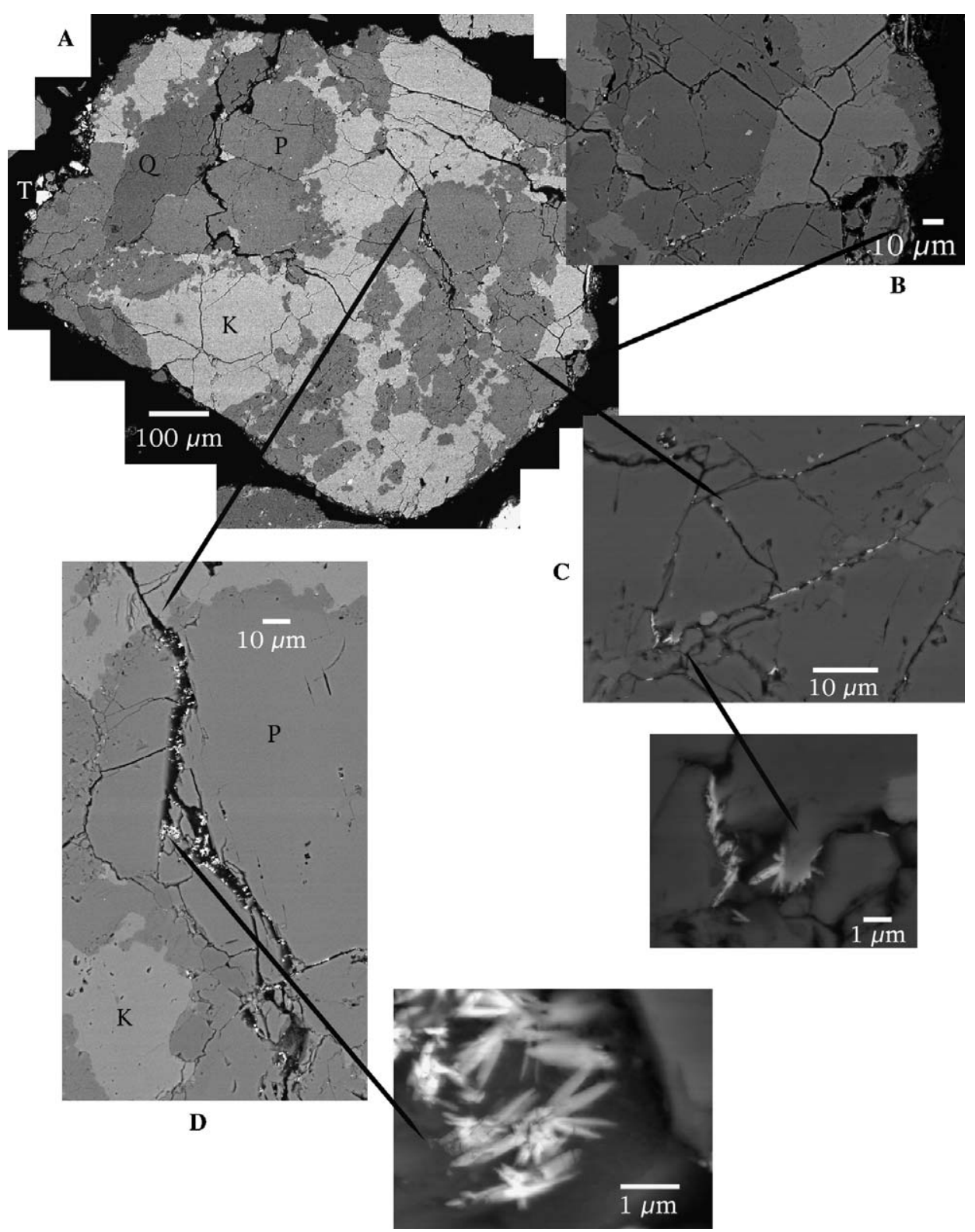

Fig. 4. Backscattered electron images of uranyl silicate within microfractures of a single granitic clast, in thin section. (A) Photomosaic of full clast, (B-D) uranyl silicate precipitates in fractures progressively further from the clast surface. Q, quartz; P, plagioclase; K, potassium feldspar; and T, titanomagnetite. Successive images show details of the uranyl silicate habit. The fine uranyl silicate crystals occupy microfractures, and are associated with plagioclase.

In those experiments, the model-specific solid (sodium boltwoodite) was chosen after evaluating the leachate concentrations against a set of mineral solubilities. The spectroscopic/X-ray diffraction results from these same sediment samples (Catalano et al., 2004) were more constraining, but also could not be considered to be definitive, because identification of uranyl silicate phases by EXAFS analysis is difficult due to similarities in X-ray spectra, multiple scattering, and spectral interferences (Catalano and Brown, 2004). The identification of sodium boltwoodite (Catalano et al., 2002) relied in part on X-ray microdiffraction from uranium-rich areas in the samples, with results that were difficult to interpret. Our results on the fracture-filling precipitates provided information that complimented the spectrographic results, but, as noted above, were similarly limited by the uranyl mineral's grain size.

The XANES spectra (Fig. 3) indicated that the fracturefill mineral included only U(VI). The compositional analysis (Table 1) indicated that it was a uranyl silicate, the most abundant group of uranyl minerals in nature. Of the uranyl silicates, the most common is $\beta$-uranophane, $\mathrm{Ca}\left(\mathrm{UO}_{2}\right)_{2}$ $\left(\mathrm{SiO}_{3} \mathrm{OH}\right)_{2}\left(\mathrm{H}_{2} \mathrm{O}\right)_{5}$, a member, like boltwoodite, of the uranophane group, all of which have a Si:U of 1:1. At first glance, the compositional analysis of the fracture-fill mineral presented in Table 1 (column in bold) was not consistent with a Si:U of 1:1, but was closer to a Si:U of 4:1 (mole calculations are presented in Table 1, with other elements proportioned to $U$ arbitrarily set to 1 ). The solubility of silica is $\mathrm{pH}$-dependent, and silica polymerizes at alkaline $\mathrm{pH}$ as 

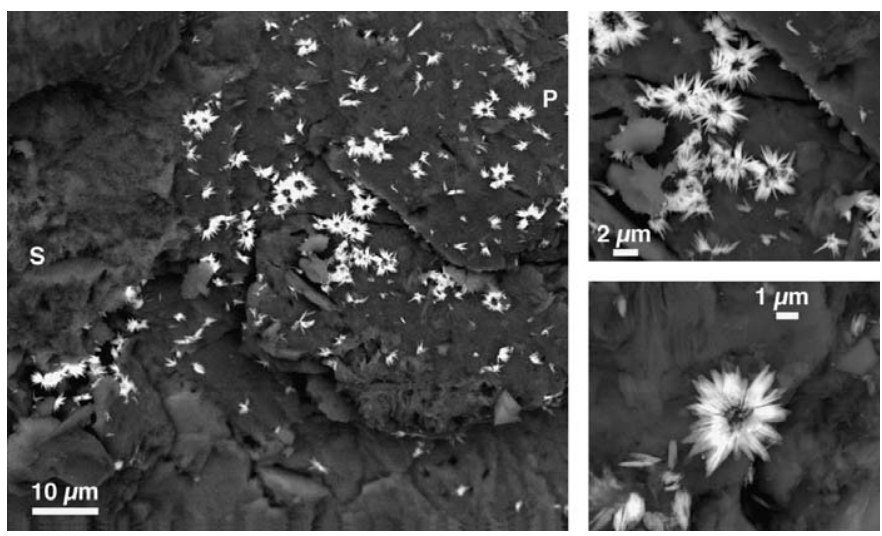

Fig. 5. Uranyl silicate florets on the face of a clast broken along a microfracture. S, secondary smectite and $\mathrm{P}$, plagioclase. Florets are defined by fine, radiating clusters.

concentration rises (Dent Glasser and Lachowski, 1980), so alkaline conditions with excess dissolved silica would seem to favor higher Si:U, and a 4:1 proportion of silicon to uranium was within the range observed in minerals and in synthesized compounds. Soddyite, $\left(\mathrm{UO}_{2}\right)_{2} \mathrm{SiO}_{4}\left(\mathrm{H}_{2} \mathrm{O}\right)_{2}$, has a ratio $(\mathrm{Si} / \mathrm{U})$ of 0.5 , and the weeksite group of uranyl minerals has a structure incorporating silica at a ratio of 2.5 (Finch and Murakami, 1999). Other, less common, minerals include uranosilite, $\left(\mathrm{UO}_{2}\right)_{2} \mathrm{Si}_{7} \mathrm{O}_{15}\left(\mathrm{H}_{2} \mathrm{O}\right)_{n}$ $(0<n<1)$, with a ratio of 3.5 (Walenta, 1974). Investigations of hydrothermal glass alteration and the synthesis of sodium-uranyl compounds (Plesko et al., 1992; Burns et al., 2000; Li and Burns, 2001), have resulted in solid compounds with a ratio of 4 , and the EMP-determined weight-percent composition of the synthesized 4:1 compound $\mathrm{KNa}_{3}\left(\mathrm{UO}_{2}\right)_{2}\left(\mathrm{Si}_{4} \mathrm{O}_{10}\right)_{2}\left(\mathrm{H}_{2} \mathrm{O}\right)_{4}$ (Burns et al., 2000 ) is included in Table 1 for comparison with our unknown. Although the weight percent data for the unknown fracture-fill mineral were comparable to the results for $\mathrm{KNa}_{3}\left(\mathrm{UO}_{2}\right)_{2}\left(\mathrm{Si}_{4} \mathrm{O}_{10}\right)_{2}\left(\mathrm{H}_{2} \mathrm{O}\right)_{4}$ (Table 1), this comparison was deceptive, and further evaluation suggested that it was not accurate.

The synthesis of the 4:1 uranyl silicates was done under hydrothermal conditions (Plesko et al., 1992; Burns et al., 2000; Li and Burns, 2001), i.e., in pressure vessels at temperatures greater than $100{ }^{\circ} \mathrm{C}$, in the presence of glasses or through the stoichiometric combination of aqueous components. In a study of mineral precipitates in a granitic uranium mine, which may be more analogous to the precipitates studied here, spanning acid to alkaline conditions, uranyl silicates with a Si:U of 4:1 were not observed (Allard et al., 1999). Also, aluminum-bearing uranyl silicate minerals are not known (Finch and Murakami, 1999), but the analysis of the fracture-fill uranyl silicates (Table 1) indicated $\mathrm{Al}_{2} \mathrm{O}_{3}$ of $10.3 \mathrm{wt} \%$. For comparison, the analysis for the phase $\mathrm{KNa}_{3}\left(\mathrm{UO}_{2}\right)_{2}\left(\mathrm{Si}_{4} \mathrm{O}_{10}\right)_{2}\left(\mathrm{H}_{2} \mathrm{O}\right)_{4}$, synthesized by hydrothermal reaction of alumina-bearing borosilicate glass, included aluminum substituted for silicon at less than one weight percent $\mathrm{Al}_{2} \mathrm{O}_{3}$ (Table 1). The alumina in our result was not part of the uranyl silicate. As discussed above, our result included contributions from substrate plagioclase feldspar, accessed by penetration through the uranyl silicates by the electron beam. If we ruled out the formation of a previously unknown aluminum-bearing uranyl silicate phase, we could conclude that the alumina in our analysis originated from the substrate, for which we could assign a nominal formula of NaAl$\mathrm{Si}_{3} \mathrm{O}_{8}$. We could therefore correct our analysis for the contribution of the substrate by subtracting the $\mathrm{Al}_{2} \mathrm{O}_{3}$ contribution and three times its molar equivalent from the $\mathrm{SiO}_{2}$ content, to achieve a composition more representative of the solid phase. The results of that calculation, also assigning $3 \mathrm{H}_{2} \mathrm{O}$, analogous to sodium boltwoodite, are presented in Table $1(R \mathrm{wt} \%)$, along with the weight percent equivalent composition calculated from the sodium boltwoodite mineral formula, $\mathrm{Na}_{2}\left(\mathrm{UO}_{2}\right)_{2}\left(\mathrm{SiO}_{3} \mathrm{OH}\right)_{2} 3 \mathrm{H}_{2} \mathrm{O}$.

Table 1

Normalized weight percent compositions, determined by EDS, for fracture-fill uranyl silicate (bold), with standard deviations for eight measurements

\begin{tabular}{|c|c|c|c|c|c|c|c|}
\hline \multirow[t]{2}{*}{ Oxide } & \multirow[t]{2}{*}{ KNAURSI $^{\mathrm{a}}($ wt. $\%)$} & \multicolumn{5}{|c|}{ Fracture-fill uranium silicate } & \multirow[t]{2}{*}{ Na-Boltwoodite ${ }^{\mathrm{b}}$ (wt.\%) } \\
\hline & & Wt. $\%$ & $1 \sigma^{\mathrm{c}}$ & Moles $^{\mathrm{d}}$ & $1 \sigma$ range $(\mathrm{mol})$ & $R(\mathrm{wt} . \%)^{\mathrm{e}}$ & \\
\hline $\mathrm{Na}_{2} \mathrm{O}$ & 8.02 & 2.0 & 0.70 & 0.387 & $0.25-0.52$ & 3.0 & 7.45 \\
\hline $\mathrm{CaO}$ & 0.13 & $\mathbf{0}^{\mathrm{f}}$ & 2.2 & 0 & $0.00-3.14$ & & \\
\hline $\mathrm{UO}_{3}$ & 41.45 & 48.1 & 7.2 & 1.0 & $0.85-1.15$ & 73.0 & 69.21 \\
\hline $\mathrm{SiO}_{2}$ & 38.37 & 38.5 & 9.6 & 3.815 & $2.86-4.77$ & 15.3 & 14.57 \\
\hline $\mathrm{Al}_{2} \mathrm{O}_{3}$ & 0.86 & 10.3 & 2.1 & 1.196 & $0.94-1.45$ & & \\
\hline
\end{tabular}

Also presented are mineral compositions for comparison, and a recalculation of EDS results based on the elimination of a hypothetical feldspar component.

a "Potassium sodium uranium silicate," electron microprobe analysis (Burns et al., 2000).

${ }^{b}$ Ideal values calculated from mineral formula, $\mathrm{Na}_{2}\left(\mathrm{UO}_{2}\right)_{2}\left(\mathrm{SiO}_{3} \mathrm{OH}\right)_{2} \cdot 3 \mathrm{H}_{2} \mathrm{O}$.

${ }^{c}$ Standard deviation, in $\mathrm{wt} \%$, of eight energy dispersive X-ray analyses.

d Calculated from $\mathrm{wt} \%$ data, normalized to $U=1$.

${ }^{\mathrm{e}}$ Recalculated, normalized $\mathrm{wt} \%$ based on removal of $\mathrm{Al}$ and three times the equivalent $\mathrm{Si}$ from measured values, and assigning $3 \mathrm{H}_{2} \mathrm{O}$, see text.

${ }^{\mathrm{f}}$ Based on SD greater than one-half the mean for eight measurements of $\mathrm{Ca}(1 \sigma /$ mean was 1.0$)$.

${ }^{g} \mathrm{H}_{2} \mathrm{O}$ could not be estimated in our analyses. 


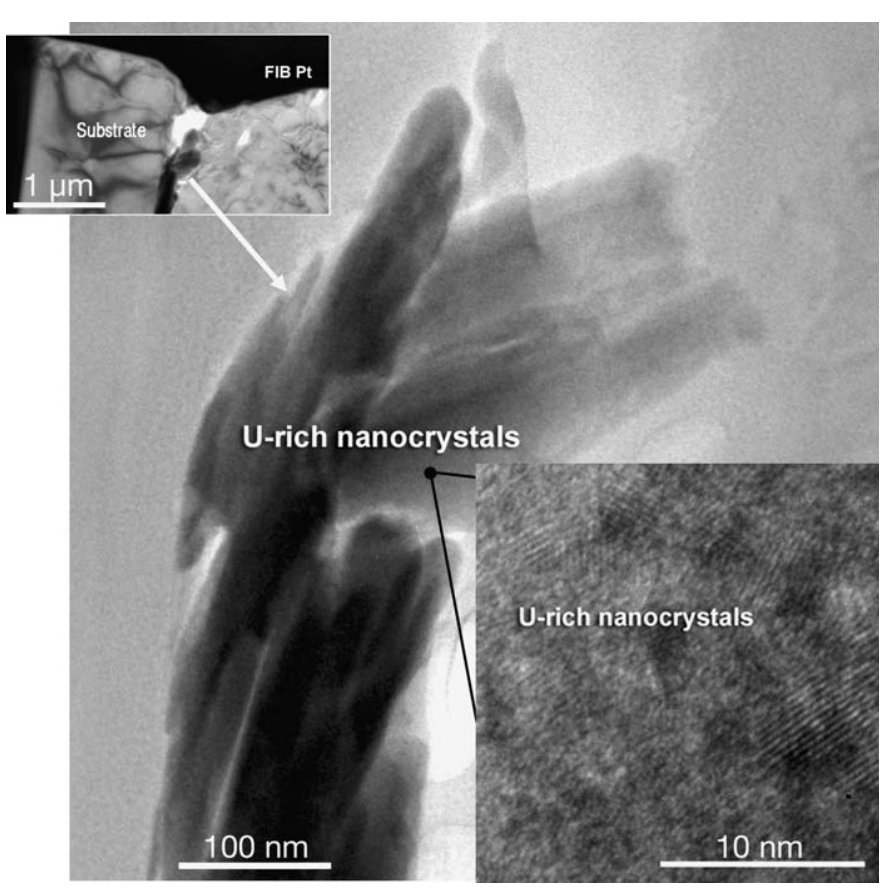

Fig. 6. TEM images at increasing magnification of nanocrystalline uranyl silicate in a microfracture.

The calculated compositions for fracture fill and sodium boltwoodite were similar. (Note that the original analysis included a molar ratio for $\mathrm{Al}: \mathrm{Si}$ that after adjustment would leave insufficient Si for boltwoodite stoichiometry. The recalculation therefore included an increase in mean $\mathrm{SiO}_{2}$ of $0.2 \mathrm{~mol}$, and an equal decrease in $\mathrm{Al}_{2} \mathrm{O}_{3}$; both of these adjustments were well within the $1 \sigma$ standard deviation for those measurements, also given in Table 1.) Although our results were veiled by the contributions of the substrate phase, they were consistent with the results of others (Catalano et al., 2004; Liu et al., 2004), and provided chemical data that constrained the phase identity to a uranyl silicate that was probably sodium boltwoodite.

The anthropogenic mode of emplacement for uranyl silicates in the sediments at Hanford differed from the mode of deposition for uranium ore deposits, but in detail, the two processes had chemical similarities. At Hanford, uranyl was introduced into unsaturated sediments as a pulse, in a solution that contrasted chemically with the in situ conditions. In ore deposits that include uranyl minerals, relatively soluble uranyl precipitated after reaching mineral saturation along a reactive saturated flowpath. Precipitation in any case occurred microscopically, and ore deposition may have born some similarity to the formation of the anthropogenic precipitates at Hanford.

The precipitation of ore minerals was constrained by the local chemical environment (Finch and Murakami, 1999), as demonstrated by numerous studies of individual uranium mineral deposits, where deposition always represented the oxidation of U(IV) followed by the precipitation of uranyl with locally contributed mineral components. The uranyl minerals precipitated along a reactive, chemically evolving flowpath (Lofvendahl, 1981; Korzeb et al., 1997; Ibrahim et al., 2001). At the microscale, precipitation was in response to systematic compositional change, and was thus analogous to the behavior of the reactive waste plume at the BX tank farm.

The habits of the uranyl silicates we observed were similar to some mineral deposits. At a deposit in Utah, where reduction-concentrated U(IV) was oxidized, "radiating sprays of acicular [boltwoodite] crystals" were observed in the zone of secondary oxidation, among diverse copper sulfates and uranyl carbonates and oxyhydroxides. The mineral boltwoodite was originally discovered in the silicate zone of alteration immediately surrounding hydrated uraninite (Frondel and Ito, 1956), with crystals of needle-like morphology within fractures in downgradiant sandstone. Although this morphology was similar to the one we observed, it was not unique amongst the uranyl silicates; soddyite, for example has been observed in similar form (Korzeb et al., 1997). In another example, in the secondary uranium deposits in the Central Eastern Desert, Egypt, precipitation was facilitated by solute concentration during evaporation (Osmond et al., 1999), and produced idiomorphic prismatic soddyite and lamellar uranophane on rock surfaces. These natural uranyl silicates provided a chemical context for the anthropogenic uranyl silicates we studied. Natural occurrences of uranyl silicates suggested that they were favored at alkaline $\mathrm{pH}$, where silica was abundant, and could form idiomorphically in void spaces. These three conditions applied within the studied microfractures in granitic clasts during precipitation.

\subsection{Diffusion modelling}

The morphology, spatial distribution, and association of uranyl silicates with a restrictive set of minerals suggested the following conceptual model for its emplacement in granitic clast microfractures. Alkaline, sodiumrich, and silica-poor solutions were introduced into Hanford formation sediments, and included uranium that was complexed by abundant dissolved bicarbonate. The solutions wetted the surfaces of granitic sediment clasts that were penetrated by pre-existing microfractures containing solutions in thermodynamic equilibrium with respect to the clasts' mineral assemblage of plagioclase feldspar, potassium feldspar, and quartz. Waste components occupied the microfractures by diffusive processes, and mixed with the silica-rich solutions within them, causing the saturation and precipitation of uranyl silicate. The high specific surface area within the fractures facilitated the rapid dissolution of feldspars to replenish dissolved silica, and drove further uranyl precipitation. Uranyl diffusion into the fractures was driven by the concentration gradient imposed by precipitation.

A computational diffusion-reaction model was written to simulate and evaluate the conceptual model. The diffusion equation for aqueous species was 
$\frac{\partial C_{i}^{\mathrm{a}}}{\partial t}=\frac{\partial}{\partial l}\left(D_{i} \frac{\partial C_{i}^{\mathrm{a}}}{\partial l}\right)+r_{i}^{\mathrm{a}}$,

where $C_{i}^{\mathrm{a}}$ and $r_{i}^{\mathrm{a}}$ are the aqueous concentration $\left(\mathrm{M} \mathrm{L}^{-1}\right)$ and reaction rate $\left(\mathrm{M} \mathrm{t}^{-1} \mathrm{~L}^{-1}\right)$, respectively, for the formation of species $i ; l$ is the distance from the pore-fracture interface; and $t$ is time. Assuming no transport for species in the solid phase, the mass balance equation was

$\frac{\mathrm{d} C_{i}^{\mathrm{s}}}{\mathrm{d} t}=r_{i}^{\mathrm{s}}$,

where $C_{i}^{\mathrm{s}}$ and $r_{i}^{\mathrm{s}}$ are the solid concentration $\left(\mathrm{M} \mathrm{L}^{-3}\right)$ and reaction rate $\left(\mathrm{M} \mathrm{t}^{-1} \mathrm{~L}^{-2}\right)$, respectively, normalized to solution volume. Eq. (1) was a simplification of a more general multi-component diffusion model: the diffusion constant $\left(D_{i}\right)$ for all species was assumed equal, and cross-term diffusivities could be neglected; i.e., $D_{i}$ was constant and charge balance was assured.

Because diffusivity was constant, Eq. (1) could be summed for all species, with respect to their components, $j$, to yield

$\frac{\partial T_{j}^{\mathrm{a}}}{\partial t}=\frac{\partial}{\partial l}\left(D_{j} \frac{\partial T_{j}^{\mathrm{a}}}{\partial l}\right)+I_{T_{j}}$,

where $T_{j}^{\mathrm{a}}=\sum_{i}^{N_{j}} a_{j i} C_{i}^{\mathrm{a}}$ is the total concentration of component $j$ in solution; $a_{j i}$ is the stoichiometric coefficient of component $j$ in species $i$; $N_{j}$ is the number of equilibrium aqueous species containing component $j$; and $I_{T_{j}}$ is the reaction rate for component $j$.

Within the model, all species and components were assumed to be in local equilibrium, and the equilibrium speciation was calculated using GMIN (Felmy, 1995). The model ran iteratively. For each time step, Eq. (3) was first solved using activity values and reaction rates derived from the previous conditions; the aqueous phase speciation was then re-calculated using GMIN; reaction rates were reevaluated using the updated speciation; and Eq. (3) was solved again; and the process was repeated until convergence at a global relative error of less than $1 \times 10^{-5}$.

The computational model, with conceptual bounds imposed by our observations, required some additional parameterization. The uranyl silicate phase was specified to be sodium boltwoodite, with $\log K_{\mathrm{sp}}=6.08 \pm 0.50$ (Liu et al., 2004). The specification of sodium boltwoodite was apparently contradicted by TEM results, but the $K_{\mathrm{sp}}$ value was determined experimentally, using these same sediments. The influence of nanoscale heterogeneity within the fractures was captured by the experiment. It was also necessary to define and parameterize the physical and chemical components of the modelled system: the surface area to volume ratio for the microfractures; dissolution and precipitation reactions, and their rates, for the feldspar and sodium boltwoodite; the composition of the reactive waste solution occupying the sediment pore space; the composition of the ambient solution occupying the microfractures; and the important aqueous components, overall, and their diffusivities. The details of parameterization were as follows.
Simple geometric calculations based on fracture apertures (an hypothetical $0.4 \mu \mathrm{m}$ fracture aperture bounded by planar surfaces) provided a surface area:volume of $5 \times 10^{5} \mathrm{~m}^{-1}$. The diffusivity was derived from dissolution experiments performed with these same sediments (Liu et al., 2004), and the length-normalized diffusivity of all species was set at $D / L^{2}=7.2 \times 10^{-5} \mathrm{~s}^{-1}$. Because the model was length-normalized, its distances were dimensionless, allowing time-dependent interpretations for fractures of specified arbitrary length. The model was divided into 50 computational cells, which were solved sequentially for all species. Uranyl silicate was observed to be copiously precipitated on fracture faces (Fig. 4), but occurred in clusters. We concluded that the initiation of mineral precipitation was inhibited near pre-existing crystals. The model was therefore simplified by constraining it to allow precipitation within a single model fracture at four randomly selected points.

The dissolution rates for feldspars were known to be dependent on chemistry, surface area, and $\mathrm{pH}$ (Knaus and Wolery, 1986; Gautier et al., 1994; Hodson, 1999; Teng et al., 2001). The dissolution reaction could be represented

$\mathrm{NaAlSi}_{3} \mathrm{O}_{8}+2 \mathrm{H}_{2} \mathrm{O}=\mathrm{Na}^{+}+\mathrm{Al}(\mathrm{OH})_{4}{ }^{-}+3 \mathrm{SiO}_{2(\mathrm{aq})}$

We used a rate expression for feldspar that incorporated pH and affinity (Gautier et al., 1994; Stefansson and Arnorsson, 2000), with an intrinsic dissolution constant (Chou and Wollast, 1985), $k_{+}$, of $3.16 \times 10^{-12} \mathrm{~mol} \mathrm{~m}^{-2} \mathrm{~s}^{-1}$ :

$r=k_{+}(1-\exp (-A / 3 R T))$.

Na-boltwoodite was used as a model for the uranyl precipitates within microfractures according to:

$$
\begin{aligned}
& \mathrm{UO}_{2}\left(\mathrm{CO}_{3}\right)_{2}^{2-}+\mathrm{Na}^{+}+\mathrm{H}_{4} \mathrm{SiO}_{4}+3 \mathrm{OH}^{-} \\
& \quad=\mathrm{Na}\left(\mathrm{UO}_{2}\right)\left(\mathrm{SiO}_{3} \mathrm{OH}\right)\left(\mathrm{H}_{2} \mathrm{O}\right)_{1.5}+1.5 \mathrm{H}_{2} \mathrm{O}+2 \mathrm{CO}_{3}{ }^{2-}
\end{aligned}
$$

The precipitation of sodium boltwoodite was assumed to follow the inverse of the expression used to describe its dissolution (Liu et al., 2004),

$r=k_{-}\left(\frac{\mathrm{IAP}}{K_{\mathrm{sp}}}-1\right)\left\{\mathrm{UO}_{2}\left(\mathrm{CO}_{3}\right)_{2}{ }^{2-}\right\}$,

where the intrinsic precipitation constant, $k_{-}=6.37 \times 10^{-11}$, IAP is the ion activity product, $K_{\mathrm{sp}}$ is the solubility constant, and $r$ is precipitation rate.

Although the overall composition of the waste within the tank was known (Jones et al., 2001; Serne et al., 2003b), it included a significant solid phase component and evolved chemically prior to leaking. An experimental evaluation of simulated tank wastes and their compositional evolution upon neutralization provided a point of comparison for disposed wastes and significant solution components migrating with the waste plume (Table 2). Overall, however, the experimental result varied little from the tank inventory. The plume composition within the sediment column was therefore estimated by evaluating the 
Table 2

Estimates of tank-waste compositions, experimentally derived leakedwaste compositions, and pore and fracture solution compositions used for diffusion modelling

\begin{tabular}{lllll}
\hline Component & \multicolumn{3}{l}{ Solution concentration $(\mathrm{M})$} & \\
\cline { 2 - 5 } & Tank $^{\mathrm{a}}$ & Experiment $^{\mathrm{b}}$ & Pore & Fracture \\
\hline $\mathrm{UO}_{2}{ }^{2+}$ & 0.114 & 0.110 & 0.1 & 0 \\
$\mathrm{Na}^{+}$ & 2.92 & 1.717 & 1.625 & 0.000056 \\
$\mathrm{Ca}^{+}$ & 0.013 & 0.0003 & 0.00157 & 0.00088 \\
$\mathrm{~K}^{+}$ & 0.003 & - & 0.0027 & 0.0028 \\
$\mathrm{H}_{4} \mathrm{SiO}_{4}$ & 0.004 & - & 0.0005 & 0.00195 \\
$\mathrm{Al}(\mathrm{OH})_{4}{ }^{-}$ & 0 & 0.0001 & 0.0 & 0.000005 \\
$\mathrm{CO}_{3}{ }^{2-}$ & 0.640 & 0.547 & 0.302 & 0.00006 \\
$\mathrm{NO}_{3}{ }^{-}$ & 0.53 & 0.678 & 1.224 & 0.005 \\
$\mathrm{PO}_{4}{ }^{2-}$ & 0.36 & 0.758 & 0 & 0 \\
$\mathrm{pH}$ & $10.5^{\mathrm{b}}$ & - & 9.0 & 7.0 \\
\hline
\end{tabular}

a Estimates from process inventories (Jones et al., 2001).

b Serne et al. (2003a).

composition for equilibrium-imposed modifications (Allison et al., 1991). $\mathrm{Ca}^{2+}$ was added as a component with a fixed concentration of $0.0003 \mathrm{~mol} \mathrm{~L}^{-1}$, although its concentration in tank wastes was negligible, based on the assumption that dissolved $\mathrm{Na}^{+}$(present in tank wastes at almost 3 mol L${ }^{-1}$, Table 2) would displace sorbed $\mathrm{Ca}^{2+}$ from sediments and make it available for precipitation reactions. The $\mathrm{pH}$ was set at 9.0. These approximations indicated that $\mathrm{PO}_{4}{ }^{2-}$ would be completely removed from solution as hydroxyapatite, $\mathrm{Ca}_{5}\left(\mathrm{PO}_{4}\right)_{3}(\mathrm{OH})$. The solution was also predicted to be saturated with respect to calcite, but was undersaturated with respect to sodium boltwoodite. The composition of the solution occupying sediment pore space was estimated as shown in Table 2, allowing for the removal of $\mathrm{PO}_{4}{ }^{2-}$ and approximately one half the original $\mathrm{CO}_{3}{ }^{2-}$, and achieving charge balance by adjusting the non-reactive component $\mathrm{NO}_{3}{ }^{-}$. This compositional estimate was used with the realization that it was reasonable but imprecise, and that the composition of the downward-migrating, reacting solution was additionally a function of space and time.

The composition of the solution occupying microfractures prior to waste infiltration was estimating by first fixing the $\mathrm{pH}$ in the uncontaminated sediment, based on the $\mathrm{pH}$ of water collected by ultracentrifugation (Serne et al., 2002) and of $\mathrm{pH}$ measured in ground waters from feldspar-saturated volcanic terrains (Stefansson and Arnorsson, 2000), at $\mathrm{pH} \mathrm{7,} \mathrm{then} \mathrm{using} \mathrm{a} \mathrm{chemical} \mathrm{speciation}$ code to constrain dissolved components (Allison et al., 1991). The microfracture composition (Table 2) was assumed in equilibrium with atmospheric $\mathrm{CO}_{2}$, amorphous gibbsite $\left(\mathrm{Al}(\mathrm{OH})_{3}\right)$, amorphous silica, albite, calcite, and potassium feldspar, consistent with studies of feldspar weathering and theoretical studies of weathering in granitic terrains (Helgeson et al., 1969).

In the model, nine aqueous components were considered to define the important reactants in the pore water-microfracture system. These included $\mathrm{UO}_{2}{ }^{2+}, \mathrm{Ca}^{2+}, \mathrm{Na}^{+}, \mathrm{K}^{+}$,
$\mathrm{H}_{4} \mathrm{SiO}_{4}, \mathrm{CO}_{3}{ }^{2-}, \mathrm{NO}_{3}{ }^{-}, \mathrm{Al}(\mathrm{OH})_{3}{ }^{-}$, and $\mathrm{pH}$ (Table 2). The aqueous speciation of the components was constrained after preliminary simulations using species compiled in the MINTEQA2 (Allison et al., 1991) and GMIN (Felmy, 1995) thermodynamic databases. Only species that contributed more than $5 \%$ to the total concentration of any component were included in the calculations. Under boundary and initial conditions, these included 16 species: $\mathrm{UO}_{2} \mathrm{CO}_{3}{ }^{0}, \mathrm{UO}_{2}\left(\mathrm{CO}_{2}\right)_{2}{ }^{2-}, \mathrm{UO}_{2}\left(\mathrm{CO}_{3}\right)_{3}{ }^{4-}, \mathrm{UO}_{2} \mathrm{Ca}_{2}\left(\mathrm{CO}_{3}\right)_{3}{ }_{3}$, $\mathrm{CO}_{3}{ }^{2-}, \mathrm{HCO}_{3-}, \mathrm{H}_{2} \mathrm{CO}_{3}{ }^{0}, \mathrm{H}_{4} \mathrm{SiO}_{4}{ }^{0}, \mathrm{H}_{3} \mathrm{SiO}_{4}{ }^{-}, \mathrm{Ca}^{2+}, \mathrm{Na}^{+}$, $\mathrm{NO}_{3}{ }^{-}, \mathrm{H}^{+}, \mathrm{K}^{+}, \mathrm{Al}(\mathrm{OH})_{3}{ }^{0}, \mathrm{Al}(\mathrm{OH})_{4}{ }^{-}$.

Results of the model simulation are shown in Fig. 7. The graphical representation provides distance in dimensionless units, but computation of saturation indices and concentrations required that distances be specified. The fracture length for those calculations was arbitrarily set at $1 \mathrm{~mm}$, similar to fracture lengths in actual granitic clasts (Fig. 4). The evolution of the saturation index $(\mathrm{SI}=$ $\log \mathrm{IAP} / K_{\mathrm{sp}}$ ) for sodium boltwoodite is shown in Fig. 7a. Under initial conditions, saturation was immediately reached at the fracture opening as alkaline waste solutions mixed by diffusion with neutral silica-rich solutions within the fracture. As diffusion and reaction progressed, the zone of high supersaturation migrated into the fracture, eventually reaching a steady state at near-saturation conditions after long reaction time $\left(>10^{5} \mathrm{~s}\right)$. After $1000 \mathrm{~s}$, the saturation index was near zero (equilibrium) at the fracture opening, but sodium boltwoodite was still supersaturated in the fracture interior. At steady state $\left(>10^{5} \mathrm{~s}\right)$, sodium boltwoodite was at or below saturation at the fracture opening and very slightly supersaturated in the fracture interior. Two compositional profiles illustrate the evolution of the fracture interiors. After $1000 \mathrm{~s}$ (Fig. 7b), total silica defined an increasing concentration gradient away from the fracture opening, and total uranium and $\mathrm{pH}$ decreased toward the interior. These gradients were the consequence of reaction within the fracture to precipitate sodium boltwoodite, and of diffusion to distribute solute components along them. The progression of supersaturation into the fracture interior and the approach to an SI of 0 at the fracture opening was consistent with the observations of sodium boltwoodite within fractures but rarely at their openings; saturation conditions rapidly evolved to favor precipitation within the fractures. Dissolution of feldspar at the high specified surface-area-to-volume rapidly replenished the $\mathrm{H}_{4} \mathrm{SiO}_{4}$ consumed during precipitation (Eq. (4)), and feldspar dissolution and diffusion limitations acted to maintain a $\mathrm{pH}$ within the fractures below that of the waste solution. The lower $\mathrm{pH}$ and higher Si concentration toward the interior of the fractures maintained the saturation of uranyl silicates after initial rapid precipitation. At steady state (Fig. 7c), alkaline $\mathrm{pH}$ and total uranium were approximately constant, and total silica defined a shallow gradient toward the fracture interior. The extent of supersaturation lessened with time as high-pH waste gradually dominated the fractures' aqueous composition and silica was consumed through precipitation of Na-boltwoodite. At 

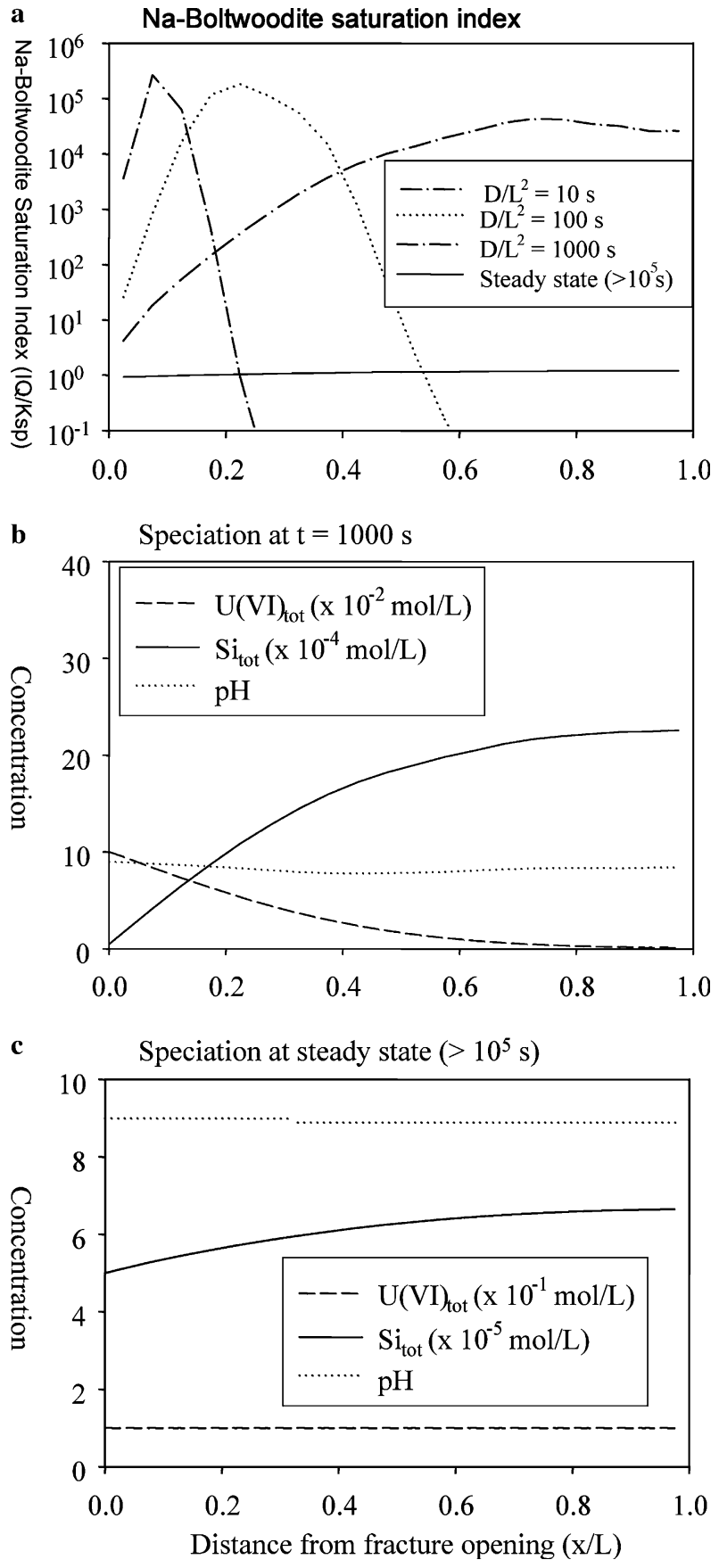

Fig. 7. Profiles of conditions within a fracture of $1 \mathrm{~mm}$ length.

steady-state conditions, the fracture interiors maintained a positive saturation index (ca. 0.1-0.2); the fracture openings were undersaturated with respect to uranyl silicates (SI $<0$; Fig. 7), as would be the external pore water.

The broadening of the saturation index gradients (and of the concentration profiles) as reaction proceeded was in part the result of cross-current diffusion of dissolved species and of dilution of the reactive species. As steady-state conditions were approached, the diffusive supply of uranyl was balanced by the dissolution of feldspar to supply silica. Also, as the saturation index overall decreased, the precipitation rate for sodium boltwoodite decreased and the relative amount of precipitated solid became insignificant. Within the simulations, the amount of sodium boltwoodite precipitated over the effective life of the reactive system was dependent on values of the kinetic rate parameter, $k_{-}$Eq. (7). Simulations with varying values of $k_{-}$showed that higher $k_{-}$yielded more precipitation, but that the precipitation rate decreased similarly as equilibrium was approached. The drop in precipitation rate was the result, according to the rate expression (Eq. (7)), of lower saturation index, and of the decrease in $\mathrm{UO}_{2}\left(\mathrm{CO}_{3}\right)_{2}{ }^{2-}$ in favor of $\mathrm{UO}_{2}\left(\mathrm{CO}_{3}\right)_{3}{ }^{4-}$ with increasing $\mathrm{pH}$. The fracture was thus rapidly populated by clusters of sodium boltwoodite when disequilibrium was maximal.

The integrated, time-dependent precipitation of sodium boltwoodite at four points in a single hypothetical fracture is illustrated in Fig. 8. Close to the grain surface $(X /$ $L=0.025$, where $X$ is the position within the fracture and $L$ is the length of the fracture, i.e., the distance is relative and dimensionless), the net accumulation of sodium boltwoodite was small and relatively invariant over time. Deeper, much more of the mineral accumulated, although the rate of accumulation slowed with time. The release of silica from mineral dissolution and the buffering of solution $\mathrm{pH}$ promoted uranium deposition within the fracture. Again, the model conformed to observation.

The preferential association of uranyl silicates with plagioclase feldspars in the plagioclase-quartz-potassium feldspar assemblage may have been due to the conditions within the microfractures during precipitation. The uranyl and silica comprising the precipitated secondary phase were replenished during uranyl silicate crystal growth. Uranyl was available through diffusion from intergranular pore space, but silica was only rapidly available through the dissolution of fracture-lining silicate minerals. The dissolution rates for albite and potassium feldspar are thought to be similar and to operate through the same mechanism (Helgeson et al., 1984; Oelkers and Schott, 1995), but

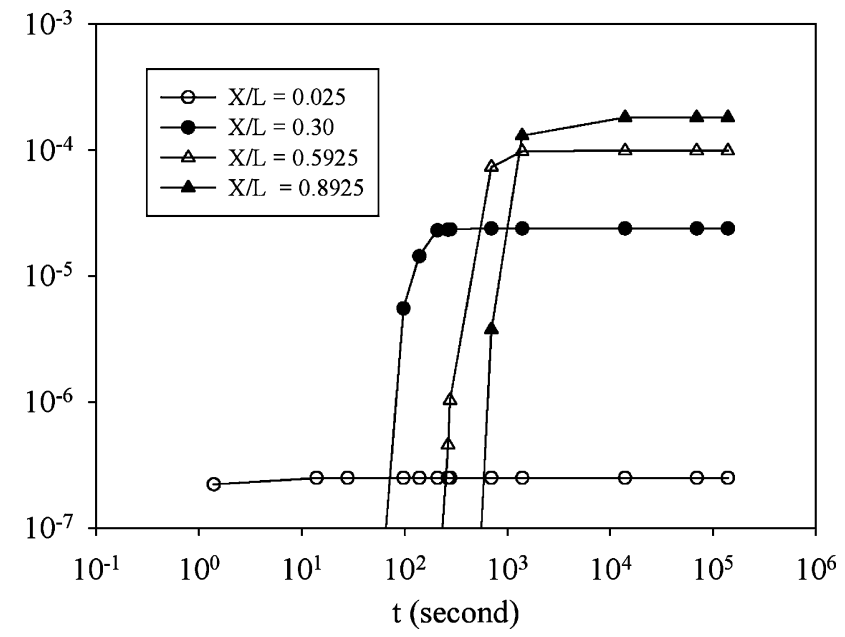

Fig. 8. Calculated sodium boltwoodite precipitation in a single microfracture. Distance within the fracture, $X$, is expressed also as a fractional, non-dimensional unit, $X / L$. 
experimental data suggest that the dissolution rate for plagioclase is more rapid than that for potassium feldspar, and is proportionally faster as the anorthite component increases (Oelkers and Schott, 1995; Stillings and Brantley, 1995). After nucleation, the dissolution of plagioclase feldspar in these sediments may thus have supplied silica at a rate that favored the consumption of uranyl near plagioclase surfaces.

\section{Concluding statement}

The examination of sediment samples from beneath the BX tank farm showed that uranium had been partially extracted from the waste solution as the massive 1951 waste plume migrated to the water table. Anecdotal information and down-hole gamma monitoring of uranium-daughter ${ }^{238} \mathrm{Pr}$ indicated that the uranium migrated rapidly. The uranium formed sodium boltwoodite that precipitated preferentially in microfractures within granitic lithic fragments occupying a small fraction of the total sediment volume. As hypothesized, the segregation of uranyl was driven by the compositional contrast between the migrating waste solution and in situ solutions occupying the fractures. The contrast was sustained by the rapid dissolution of fracture-lining silicate minerals in a physical environment that allowed dissolved silica to be replenished and maintained the $\mathrm{pH}$ at relatively low values where sodium boltwoodite would be supersaturated. Uranyl was removed from the pore space by diffusion into the microfractures. The occurrence of solid-phase uranium in fractures and not in pore space may be due to the transient nature of the environment that drove precipitation: the sediment desaturated due to capillary forces in the Vadose Zone without reaching general, pore-space saturation with respect to the uranyl silicates. The precipitated uranyl silicate is now immobile under the geochemical and hydrologic regime in the Hanford Vadose Zone, even though uranium often shows high subsurface mobility at the Hanford site.

The physical and chemical form of the precipitate was a natural consequence of anthropogenic changes to the subsurface environment. Responses to disequilibrium after anthropogenic disturbances are usually more difficult to observe because the contrasts between most solid and aqueous disequilibrium assemblages are not as marked as they were here. The occurrence of sodium boltwoodite in microfractures was comparable to its occurrence in natural deposits. In the deposit at the Delta Mine, Utah, for example, encrustations of boltwoodite were observed with other minerals immediately around oxidized uraninite, but boltwoodite was also observed as fine acicular crystals in rock fractures at some distance from the uraninite (Frondel and Ito, 1956). The sodium boltwoodite in microfractures was analogous to the macroscopic migration of uranyl-rich solutions along a reacting flowpath to a point where boltwoodite became supersaturated; the disequilibrium-driven processes were the same. The process of uranyl silicate formation and the removal of uranyl from pore space that we described here, however, was one in which a restricted and relatively isolated microscale chemical environment drove geochemical processes that removed uranyl from porewaters whose chemistry was relatively unaffected. The driver for this process was microscale diffusion, in contrast to macroscopic advection. Geochemical processes operating at microscale could be significant and unrecognized drivers of change in other natural environments as well.

\section{Acknowledgments}

This research was supported by the U.S. Department of Energy (DOE) through the Environmental Management Sciences Program (EMSP) and the Hanford Vadose Zone Characterization Project managed by $\mathrm{CH} 2 \mathrm{M}$ Hill, providing both Financial support and the U(VI) contaminated sediments. Pacific Northwest National Laboratory (PNNL) is operated for the Department of Energy by Battelle. We thank Associate Editor Dr. Leslie Warren and three reviewers for their valuable comments and suggestions on the manuscript.

\section{Associate editor: Lesley A. Warren}

\section{References}

Abdelouas, A., Lutze, W., Nuttall, H.E., 1999. Uranium contamination in the subsurface: characterization and remediation. In: Burns, P.C., Finch, R. (Eds.), Uranium: Mineralogy, Geochemistry, and the Environment, vol. 38. Mineralogical Society of America, pp. $433-473$.

Allard, T., Ildefonse, P., Beaucaire, C., Calas, G., 1999. Structural chemistry of uranium associated with $\mathrm{Si}, \mathrm{Al}, \mathrm{Fe}$ gels in a granitic uranium mine. Chem. Geol. 158, 81-103.

Allison, J.D., Brown, D.S., Novo-Gradac, K.J., 1991. MINTEQA2/ PRODEFA2, A Geochemical Assessment Model for Environmental Systems: Version 3.0 User's Guide, US EPA, p. 106.

ASTM, 1988. Standard Test Method for Total and Organic Carbon in Water by High Temperature Oxidation and by Coulometric Detection, D4129-88. American Society for Testing and Materials.

ASTM, 1998. Test Method for Laboratory Determination of Water (Moisture) Content of Soil and Rock, D2216-98. American Society for Testing and Materials.

Baes Jr., C.F., Mesmer, R.E., 1976. The Hydrolysis of Cations. Wiley, New York.

Barnes, C.E., Cochran, J.K., 1993. Uranium geochemistry in estuarine sediments: controls on removal and release processes. Geochim. Cosmochim. Acta 57, 555-569.

Bjornstad, B.N., 1990. Geohydrology of the 218-W-5 Burial Ground, 200-West Area, Hanford Site, PNL-7336. Pacific Northwest Laboratory, p. 25.

Burns, P.C., Olson, R.A., Finch, R.J., Hanchar, J.B., Thibault, Y., 2000. $\mathrm{KNa}_{3}\left(\mathrm{UO}_{2}\right)_{2}\left(\mathrm{Si}_{4} \mathrm{O}_{10}\right)_{2}\left(\mathrm{H}_{2} \mathrm{O}\right)_{4}$, a new compound formed during vapor hydration of an actinide-bearing borosilicate waste glass. J. Nucl. Mater. 278, 290-300.

Catalano, J.G., Brown Jr., G.E., 2004. Analysis of uranyl-bearing phases by EXAFS spectroscopy: interferences, multiple scattering, accuracy of structural parameters, and spectral interferences. Am. Mineral. 89, 1004-1021.

Catalano, J.G., Heald, S.M., Zachara, J.M., Brown Jr., G.E., 2004. Spectroscopic and diffraction study of uranium speciation in contaminated vadose zone sediments from the Hanford Site, Washington state. Environ. Sci. Technol. 38, 2822-2828. 
Catalano, J.G., Zachara, J.M., Heald, S.M., Brown Jr., G.E., 2002. X-ray spectroscopic investigation of the distribution and speciation of uranium in contaminated sediments from the DOE's Hanford Site. Eos Trans. AGU, V61C-10.

Chernov, D.C., 2000. Electron Flight Simulator. Small World LLC.

Chou, L., Wollast, R., 1985. Steady-state kinetics and dissolution mechanisms of albite. Am. J. Sci. 285, 963-993.

Christensen, J.N., Dresel, P.E., Conrad, M.E., Maher, K., DePaolo, D.J., 2004. Identifying the sources of subsurface contamination at the Hanford Site in Washington using high-precision uranium isotopic measurements. Environ. Sci. Technol. 38, 3330-3337.

Dent Glasser, L.S., Lachowski, E.E., 1980. Silicate species in solution. Part1. Experimental observations. Chem. Soc. Lond., Dalton Trans. 1980, 393-398.

Dresel, P.E., Evans, J.C., Farmer Jr., O.T., 2002. Investigation of Isotopic Signatures for Sources of Groundwater Contamination at the Hanford Site, PNNL-13763. Pacific Northwest National Laboratory, p. 25.

EPA, 2000a. Inductively-coupled plasma-atomic emission spectrometry. In: Test Methods for Evaluating Solid Waste, Physical/Chemical Methods. EPA Publication SW-846. U.S. Government Printing Office, Washington, DC.

EPA, 2000b. Inductively-coupled plasma-mass spectrometry. In: Test Methods for Evaluating Solid Waste, Physical/Chemical Methods. EPA Publication SW-846. U.S. Government Printing Office, Washington, DC.

Felmy, A.R., 1995. GMIN, a computerized chemical equilibrium program using a constrained minimization of the Gibbs free energy: summary report. In: Loeppert, R.H., Goldberg, S. (Eds.), Chemical Equilibrium and Reaction Models. Soil Science Society of America, pp. 377-407.

Finch, R., Murakami, T., 1999. Systematics and paragenesis of uranium minerals. In: Burns, P.C., Finch, R. (Eds.), Uranium: Mineralogy, Geochemistry, and the Environment, vol. 38. Mineralogical Society of America, pp. 91-179.

Frondel, C., Ito, J., 1956. Boltwoodite, a new uranium silicate. Science 124, 931 .

Garrels, R.M., Christ, G.L., 1959. Behavior of uranium minerals during oxidation. In: Garrels, R.M., Larsen, E.S. (Eds.), Geochemistry and Mineralogy of the Colorado Plateau Uranium Ores, vol. USGS, Prof. Pap. 320. U.S. Geological Survey, pp. 81-89.

Gautier, J., Oelkers, E.H., Schott, J., 1994. Experimental study of Kfeldspar dissolution rates as a function of chemical affinity at $150{ }^{\circ} \mathrm{C}$ and pH 9. Geochim. Cosmochim. Acta 58, 4549-4560.

Goldstein, J.I., Newberry, D.E., Echlin, P., Joy, D.C., Romig, A.D., Lyman, J., Fiori, C.E., Lifshin, C.E., 1992. Scanning Electron Microscopy and Xray Microanalysis, second ed. Plenum Press, New York.

Grenthe, I., 1992. Chemical Thermodynamics of Uranium. North-Holland, New York.

Heald, S.M., Brewe, D.L., Stern, E.A., Kim, K.H., Brown, F.C., Jiang, D.T., Crozier, E.D., Gordon, R.A., 1999. XAFS and micro-XAFS at the PNC-CAT beamlines. J. Syn. Rad. 6, 347-349.

Heaney, P.J., Vicenzi, E.P., Giannuzzi, L.A., Livi, K.J.T., 2001. Focused ion beam milling: a method of site-specific sample extraction for microanalysis of Earth materials. Am. Mineral. 86, 1094-1099.

Heinrich, K.F.J., 1981. Electron Beam X-ray Microanalysis. Van Nostrand Reinhold, NY.

Helgeson, H.C., Garrels, R.M., MacKenzie, F.T., 1969. Evaluation of irreversible reactions in geochemical processes involving minerals and aqueous solutions-II. Appl. Geochim. Cosmochim. Acta 33, 455-481.

Helgeson, H.C., Murphy, W.M., Aagaard, P., 1984. Thermodynamic and kinetic constraints on reaction rates among minerals and aqueous solutions. II. Rate constants, effective surface area, and the hydrolysis of feldspar. Geochim. Cosmochim. Acta 48, 2405-2432.

Hodson, M.E., 1999. Micropore surface area variation with grain size in unweathered alkali feldspars: implication for surface roughness and dissolution studies. Geochim. Cosmochim. Acta 62, 3429-3435.
Hsi, C.-K.D., Langmuir, D., 1985. Adsorption of uranyl onto ferric oxyhydroxides: application of the surface complexation site-binding model. Geochim. Cosmochim. Acta 49, 1931-1941.

Ibrahim, M.E., Saleh, G.M., Abd El-Naby, H.H., 2001. Uranium mineralization in the two mica granite of Gabal Ribdab area, South Eastern Desert, Egypt. Appl. Radiat. Isot. 55, 861-872.

Idiz, E.F., Carlisle, D., Kaplan, I.R., 1986. Interaction between organic matter and trace metals in a uranium rich bog, Kern County, California, USA. Appl. Geoch. 1, 573-590.

Jones, T.E., Simpson, B.C., Wood, M.I., Corbin, R.A., 2001. Preliminary Inventory Estimates for Single-Shell Tank Leaks in B, BX, and BY Tank Farms, RPP-73891. CH2MHill Hanford Group, p. 26.

Knaus, K.G., Wolery, T.J., 1986. Dependence of albite dissolution kinetics on $\mathrm{pH}$ and time at 25 and $70{ }^{\circ} \mathrm{C}$. Geochim. Cosmochim. Acta 50, 2481-2497.

Korzeb, S.L., Foord, E.E., Lichte, F.E., 1997. The chemical evolution and paragenesis of uranium minerals from the Ruggles and Palermo granitic pegmatites, New Hampshire. Can. Mineral. 35, 135-144.

Langmuir, D., 1978. Uranium solution-mineral equilibria at low temperatures with applications to sedimentary ore deposits. Geochim. Cosmochim. Acta 42, 547-569.

Li, Y., Burns, P.C., 2001. The structures of two sodium uranyl compounds relevant to nuclear waste disposal. J. Nucl. Mater. 299, 219-226.

Lieser, K.H., Quandt-Klenk, S., Thybusch, B., 1992. Sorption of uranyl ions on hydrous silicon dioxide. Radiochim. Acta 57, 45-50.

Liu, C., Zachara, J.M., Qafoku, O., McKinley, J.P., Heald, S.M., Wang, Z., 2004. Dissolution of uranyl microprecipitates in subsurface sediments at Hanford Site, USA. Geochim. Cosmochim. Acta 68, 4519-4537.

Lofvendahl, R., 1981. Secondary Uranium Minerals in Sweden, No. 779. Sveriges Geoloska Undersokning, p. 31.

Lomness, L.K., Kempshall, B.W., Giannuzzi, L.A., Watson, M.B., 2001. TEM of sub-micrometer particles using the FIB lift-out technique. Microsc. Microanal. 7 (Suppl 2: Proceedings), 950-951.

Mason, B., Berry, L.G., 1968. Elements of Mineralogy. W.H. Freeman and Company, San Francisco, CA.

Maya, L., 1982. Sorbed uranium(VI) species on hydrous titania, zirconia, and silica gel. Radiochim. Acta 31, 147-151.

McKinley, J.P., Zachara, J.M., Smith, S.C., Liu, C., 2005. Cation exchange reactions controlling desorption of ${ }^{90} \mathrm{Sr}^{2+}$ from coarsegrained contaminated sediments at the Hanford site, Washington, in press.

McKinley, J.P., Zachara, J.M., Smith, S.C., Turner, G.D., 1995. The influence of uranyl hydrolysis and multiple site-binding reactions on adsorption of U(VI) to montmorillonite. Clays Clay Miner. 43 (5), 586-598.

Mikami, N., Sasaki, M., Hachiya, K., Yasunaga, T., 1983. Kinetic study of the adsorption-desorption of the uranyl ion on a $\gamma-\mathrm{Al}_{2} \mathrm{O}_{3}$ surface using the pressure-jump technique. J. Phys. Chem. 87, 5478-5481.

Morris, D.E., Chisholm-Brause, C.J., Barr, M.E., Conradson, S.D., Eller, P.G., 1994. Optical spectroscopic studies of the sorption of $\mathrm{UO}_{2}{ }^{2+}$ species on a reference smectite. Geochim. Cosmochim. Acta 58, 3613 3623.

Oelkers, E.H., Schott, J., 1995. Experimental study of anorthite dissolution and the relative mechanism of feldspar hydrolysis. Geochim. Cosmochim. Acta 59, 5039-5053.

Osmond, J.K., Dabous, A.A., Dawood, Y.H., 1999. U series age and origin of two secondary uranium deposits, Central Eastern Desert, Egypt. Econ. Geol. 94, 273-280.

Plesko, E.P., Scheetz, B.E., White, W.B., 1992. Infrared vibrational characterization and synthesis of a family of hydrous alkali uranyl silicates and hydrous uranyl silicate minerals. Am. Mineral. 77, 431-437.

Prenitzer, B.I., Giannuzzi, L.A., Newman, K., Brown, S.R., Shofner, T.L., Irwin, F.A., 1998. Transmission electron microscope specimen preparation of $\mathrm{Zn}$ powders using the focused ion beam lift-out technique. Metal. Mater. Trans. A 29, 2399-2406. 
Prikryl, J.D., Jain, L., Turner, D.R., Pabalan, R.T., 2001. Uranium ${ }^{\text {VI }}$ sorption behavior on silicate mineral mixtures. J. Contam. Hydrol. 47, 241-253.

Rhoades, J.D., 1996. Salinity: electrical conductivity and total dissolved solids. In: Bigham, J.M. (Ed.), Methods of Soil Analysis, Part 3. American Society of Agronomy, pp. 417-435.

Riley, R.G., Zachara, J.M., 1992. Chemical Contaminants on DOE Lands and Selection of Contaminant Mixtures for Subsurface Science Research, DOE/ER-0547T. US Department of Energy, p. 77.

Serne, R.J., Jones, T.E., Lindberg, M.J., 2003a. Laboratory Scale Bismuth Phosphate Extraction Process Simulation to Track Fate of Fission Products, PNNL-14120. Pacific Northwest National Laboratory.

Serne, R.J., Jones, T.E., Lindberg, M.J., 2003b. Laboratory Scale Bismuth Phosphate Extraction Process Simulation to Track the Fate of Fission Products, PNNL-14120. Pacific Northwest National Laboratory, p. 100.

Serne, R.J., Last, G.V., Gee, G.W., Schaef, H.T., Lanigan, D.C., Lindenmeir, C.W., Lindberg, M.J., Clayton, R.E., LeGore, V.L., Orr, R.D., Kutnyakov, I.V., Baum, S.R., Geiszler, K.N., Brown, C.F., Valenta, M.M., Hill, T.S., 2002. Characterization of Vadose Zone
Sediment: Borehole 299-E33-45 Near BX-102 in the B-BX-BY Waste Management Area, PNNL-14083. Pacific Northwest National Laboratory, p. 100.

Stefansson, A., Arnorsson, S., 2000. Feldspar saturation state in natural waters. Geochim. Cosmochim. Acta 64, 2567-2584.

Stillings, L.L., Brantley, S.L., 1995. Feldspar dissolution at $25^{\circ} \mathrm{C}$ and $\mathrm{pH}$ 3: reaction stoichiometry and the effect of cations. Geochim. Cosmochim. Acta 59, 1483-1496.

Teng, H.H., Fenter, P., Cheng, L., Sturchio, N.C., 2001. Resolving orthoclase dissolution processes with atomic force microscopy and Xray reflectivity. Geochim. Cosmochim. Acta 65, 3459-3474.

Walenta, K., 1974. On studtite and its composition. Am. Miner. 59, 166171.

Williams, J.C., 1999. Historical Vadose Zone Contamination from B, BX, and BY Tank Farm Operations, RPP-5231. Fluor Daniel Northwest.

Zachara, J.M., McKinley, J.P., 1993. Influence of hydrolysis on the sorption of metal cations by smectites: Importance of edge coordination reactions. Aquat. Sci. 55 (4), 250-261. 